\title{
Climate Variability and Change, Impacts and Adaptation Strategies in Dutsin-Ma Local Government Area of Katsina State, Nigeria
}

\author{
Abaje, I. B. ${ }^{1}$, Sawa, B. A. ${ }^{2}$ \& Ati, O. F. ${ }^{1}$ \\ ${ }^{1}$ Department of Geography and Regional Planning, Federal University Dutsin-Ma, Nigeria \\ ${ }^{2}$ Department of Geography, Ahmadu Bello University, Zaria, Nigeria \\ Correspondence: Abaje, I. B., Department of Geography and Regional Planning, Federal University Dutsin-Ma, \\ Nigeria. Tel: 234-802-794-2167. E-mail: abajebest@gmail.com
}

\author{
Received: December 27, 2013 Accepted: January 15, 2014 Online Published: May 3, 2014 \\ doi:10.5539/jgg.v6n2p103 \\ URL: http://dx.doi.org/10.5539/jgg.v6n2p103
}

\begin{abstract}
This paper aimed at examining local peoples' perceptions on climate variability and change and strategies adopted in combating the impacts of the changes in Dutsin-Ma Local Government Area of Katsina State. A total of 242 questionnaires were administered to households' heads in the eleven wards of the Local Government Area. Descriptive statistics such as frequency distribution, percentage and mean scores were used in data analysis. The result revealed that majority of the local people have a very good knowledge of climate variability and change in terms of higher temperature, higher rainfall intensity and variability, and the occurrence of extreme weather events such as flood and drought. Findings also revealed that community disobeying God, deforestation, bush burning, combustion of fossil fuel and pollution were the major causes of climate variability and change as perceived by the respondents. The most significant impacts of climate variability and change as perceived by the local people were decline in crop yields, decline in forest resources, water shortages and decrease in soil fertility. These impacts have resulted to rural-urban migration in the area. Sustainable adaptation strategies adopted by the local people are water harvesting, the use of fertilizer/animals dung to improve crop yield, irrigation agriculture, planting of crop varieties and drought resistant crops. It is recommended that strategies for combating impacts of climate variability and change should take into account the traditional and religious beliefs of the people; and there is need to educate the local people to appreciate the scientific basis of climate variability and change.
\end{abstract}

Keywords: adaptation, climate change, impacts, perception, resources, variability

\section{Introduction}

Climate variability and change is one of the greatest socioeconomic and biophysical challenges confronting the world in the $21^{\text {st }}$ century. It is brought about by the complex interactive of the climate system (atmosphere, oceans, cryosphere, surface lithosphere, and biosphere) (Le Treut et al., 2007). Several observations of the behavior of the climate system by various scientists over the past decades to the present have highlighted the rate at which the system is currently changing (Steffen, 2009).

Reports of the IPCC (2007c) have highlighted the vulnerability of Africa to climate variability and change. Even though they are least responsible for these changes, they are prone to greater impacts because their economies are highly dependent on natural resources that are sensitive to climate in addition to the fewer resources and options they have to combat the impacts of climate variability and change. Millions of its people may likely face catastrophes, and extreme weather events are likely to become more intense and more frequent with higher global temperatures affecting crops, water supplies and increase spread of diseases among other impacts. The projected impacts of climate variability and change for Africa by 2020 is between 75 and 250 million people (IPCC, 2007c). This will adversely affect the livelihoods of the people.

The climate of Nigeria has shown considerable temporal and spatial shifts in its variability and change since the late 1960s and early 1970s through a careful study of meteorological data (Federal Republic of Nigeria, 2003; Nigerian Meteorological Agency, 2012). Extreme weather and climate events such as drought, flood, ocean surges, etc. have become more regular. The impacts of these extreme events may be gradual but their destruction to lives and property has a negative impact on the economy. Floods have become an almost annual occurrence especially in the northern parts of the country with increasing intensity each year, leaving colossal losses and 
trauma (Abaje \& Giwa, 2010; Nigerian Meteorological Agency, 2012). Adaptation to climate variability and change refers to all those responses that may be adopted by people to reduce vulnerability (Federal Republic of Nigeria, 2003). It has the potential to alleviate adverse impacts, as well as to capitalize on new opportunities posed by climate variability and change.

Previous researches have shown that different areas and environments are affected by climate change differently; as a result, people will equally be faced with different aspects of climate variability and change depending on where they live. For examples, Jan and Anja (2007) in their research work titled "Indigenous Peoples and Climate Change" divided the world into six broad environmental categories as follows: Polar Regions, Alpine areas, Deserts, Tropical Rainforests, Islands, and Temperate ecosystems. The result of their study revealed that different areas and people are affected by climate change differently depending on their location. Similarly, Ishaya and Abaje (2008) studied people's perception on climate change and adaptation strategies using five wards in Jema'a Local Government Area (LGA) of Kaduna State equally found out that the impacts of climate change on the people varied from one ward to another depending on the location and environmental conditions; as a result, the adaptation strategies are also not the same. Abaje, Ati, Iguisi and Jidauna (2013) studied the changing climatic scenarios of the Sudano-Sahelian Ecological Zone of Nigeria using probabilistic analysis of rainfall data revealed that the frequency of drought increases from the period 1949-1958 towards the decade 1979-1988; from that period, the zone then experienced a dramatic decline in the frequency of drought occurrences towards the recent years. Tukur, Adamu, Abdulrahid and Rabi'u (2013) also found out that fuel wood extraction provides employment (source of income) to the local people of Dutsin-Ma LGA. This is an adaptation strategy that is not sustainable because fuel wood extraction (deforestation) is one of the major causes of climate variability and change in the area.

Based on the aforementioned, vital information pertaining perceptions and adaptation of climate variability and change by the local people and communities in Dutsin-Ma LGA of Katsina State is still needed. These information and awareness are very important so that the local people will be more conscious about the imminent impacts of these changes on their environment.

The objectives of this research, therefore, are to: 1) find out local peoples' perceptions of what climate variability and change means in Dutsin-Ma LGA; 2) assess the perceived causes of climate variability and change in the area; 3) examine the impacts of climate variability and change on their livelihoods; and 4) examine adaptation strategies used by the local people in combating the impacts of climate variability and change.

\section{Study Area}

Dutsin-Ma LGA lies on latitude $12^{\circ} 26^{\prime} \mathrm{N}$ and longitude $07^{\circ} 29^{\prime} \mathrm{E}$. It is bounded by Kurfi and Charanchi LGAs to the north, Kankia LGA to the east, Safana and Dan-Musa LGAs to the west, and Matazu LGA to the southeast. Dutsin-Ma LGA has a land size of about $552.323 \mathrm{~km}^{2}$ with a population of 169829 as at 2006 national census (Federal Republic of Nigeria, 2012). The people are predominantly farmers, cattle rearers and traders.

The climate of Katsina State is the tropical wet and dry type (tropical continental climate) classified by Koppen as Aw climate. Rainfall is between May and September with a peak in August. The average annual rainfall is about $700 \mathrm{~mm}$. The pattern of rainfall in the area is highly variable. This can result in severe and widespread droughts that can impose serious socio-economic constraints (Abaje, Ati, \& Iguisi, 2012). The mean annual temperature ranges from $29{ }^{\circ} \mathrm{C}-31^{\circ} \mathrm{C}$. The highest air temperature normally occurs in April/May and the lowest in December through February. Evapo-transpiration is generally high throughout the year. The highest amount of evaporation occurs during the dry season. The vegetation of the area is the Sudan Savanna type which combines the characteristics and species of both the Guinea and Sahel Savanna (Abaje, 2007; Tukur et al., 2013)

\section{Materials and Methods}

Data and information for this research work were obtained from a field study based on the result of 242 questionnaires administered to household heads in Dutsin-Ma LGA of Katsina State in July, 2013. A total of 22 questionnaires were administered to each of the 11 wards of the LGA namely: Dutsin-Ma 'A', Dutsin-Ma 'B', Makera, Karofi 'A', Karofi 'B', Bagagadi, Kuki 'A', Kuki 'B', Dabawa, Shema, and Kutawa. Eleven research assistants (each representing a ward) specializing in geography were trained to conduct the interview. The questionnaires were purposively administered to household heads who are 40 years and above, and must have been residing in the area for at least 30 years. The basis for this was to gather information from respondents who have had experiences in climate variability and change over the years and are more concerned and conscious about the imminent impacts of these changes on their environment. Only respondents who were willing and interested on the subject matter were purposively administered questionnaires. The respondents were selected from each category of people depending on who is the head of a given household. In addition, a Focus Group 
Discussion (FGD) of eleven people (one representative from each of the 11 wards of the LGA) was also held in July 2013 at Dutsin-Ma 'A' ward in order to obtain in-depth information on recent environmental changes, changes in agricultural and livestock productivity, disaster preparedness and adaptation strategies of the communities.

The analysis of the collected data was based on descriptive statistics and likert scale. The interview schedule had four sections. Section 'A' sought information on the socio-economic characteristics of the respondents. Simple descriptive statistics such as mean, percentage and frequency distribution were used to describe the socioeconomic characteristics of the respondents. Information gathered from each of the 242 respondents on their ages (years), household sizes, income per annum, and years living in the area were subjected to descriptive statistics using Microsoft Excel 2013 in order to get the means of the above four socioeconomic characteristics. Section 'B' sought information on climate variability and change and their causes as perceived by the local people. A list of measures was provided for the respondents to tick the appropriate option of "agree", "undecided" and "disagree". Data collected on this section were presented as percentage of the respondents. Impacts of climate change and variability in Section ' $\mathrm{C}$ ' of the interview schedule was placed on a five point likert scale (LS). Each respondent was required to tick any of the options namely: 'strongly agree', 'agree', 'undecided', 'disagree' and 'strongly disagree'. Values assigned to these options are 5, 4, 3, 2 and 1 respectively. Any response with mean score less than 3.0 will be taken as those which experience less impacts of climate variability and change while those with mean score equal or above 3.0 will be taken as having greater impacts. Section ' $D$ ' sought information on adaptation strategies adopted in combating the impacts of climate variability and change in the area. A five point LS was also used $(5=$ strongly agree, $4=$ agree, $3=$ undecided, $2=$ disagree and $1=$ strongly disagree). Any response option with mean score less than 3.0 was regarded as not being useful and important adaptation strategies while options with mean score equal or above 3.0 were regarded as being useful and important adaptation strategies in minimizing the impacts/effects of climate variability and change by the local people.

\section{Results and Discussions}

\subsection{Socioeconomic Characteristics of Respondents}

Table 1 shows the socioeconomics characteristics of respondents in the study area. The results of the finding show that the majority of the respondents were males (87\%) while only $13 \%$ were females. This is in agreement with other related studies for examples, Ishaya and Abaje (2008); Abraham, Bamidele, Adebola and Kobe (2012) that the agricultural sector and the tedious activities related to climate change adaptation strategies are dominated by males. The table shows that out of the 242 respondents, 36.4\% attended Quranic School, 29.3\% primary school, $19 \%$ have tertiary education, and $12.8 \%$ have secondary education, while $2.5 \%$ have no education at all. The average age of the respondents is 52 years. $52.1 \%$ are between $40-49$ years while $47.9 \%$ are 50 years and above. Age in terms of climate change adaptation in the area is an important factor. This is because the younger ones $(52.1 \%)$ that are still active and agile commit more of their energy in crop and livestock production and are conscious about the imminent impacts of these changes on their environment while the older ones (47.9\%) have had experiences in climate variability and change over the years.

The majority of the respondents $(80.6 \%)$ are married; and the average household size is 11 . The large household size is believed to provide cheap labor that will assist in practices that will mitigate the impacts of climate variability and change by the respondents. This is because some of the resources and items that could be used in combating the impacts of climate variability and change cannot be afforded as the average annual income of the respondents is $\$ 151000$. Out of the 242 respondents, $83.9 \%$ earns less than $\$ 200000$ and only $16.1 \%$ of the respondents earns above $\$ 200000$. The respondents have been living in the area for an average of 43 years and their major occupation is farming which represent $70 \%$, while $22 \%$ engaged in livestock production and others $8 \%$. This implies that, the respondents depend heavily on natural and physical resources of the environment for their livelihood. 
Table 1. Socioeconomic characteristics of respondents

\begin{tabular}{|c|c|c|c|}
\hline Household Characteristics & Frequency & Percentage & Mean \\
\hline \multicolumn{4}{|l|}{ Gender } \\
\hline Male & 211 & 87 & \multirow{6}{*}{52} \\
\hline Female & 31 & 13 & \\
\hline \multicolumn{4}{|l|}{ Age (Years) } \\
\hline $40-49$ & 126 & 52.1 & \\
\hline $50-59$ & 54 & 22.3 & \\
\hline $60-69$ & 34 & 14.0 & \\
\hline$\geq 70$ & 28 & 11.6 & \\
\hline \multicolumn{4}{|l|}{ Marital status } \\
\hline Single & 26 & 10.7 & \\
\hline Married & 195 & 80.6 & \\
\hline Divorced & 09 & 3.7 & \\
\hline Widowed & 12 & 5.0 & \\
\hline \multicolumn{4}{|l|}{ Level of education } \\
\hline Primary & 71 & 29.3 & \\
\hline Secondary & 31 & 12.8 & \\
\hline Tertiary & 46 & 19.0 & \\
\hline Quranic & 88 & 36.4 & \\
\hline No Education & 06 & 2.5 & \\
\hline \multicolumn{4}{|l|}{ Household size } \\
\hline$\leq 5$ & 47 & 19.4 & \multirow{6}{*}{11} \\
\hline $6-10$ & 97 & 40.1 & \\
\hline $11-15$ & 58 & 24.0 & \\
\hline $16-20$ & 24 & 9.9 & \\
\hline $21-25$ & 7 & 2.9 & \\
\hline$\geq 26$ & 9 & 3.7 & \\
\hline \multicolumn{4}{|l|}{ Occupation } \\
\hline Farming & 169 & 70 & \\
\hline Livestock production & 54 & 22 & \\
\hline Others & 19 & 8.0 & \\
\hline \multicolumn{4}{|l|}{ Income per annum (N) } \\
\hline$<100000$ & 84 & 34.7 & \multirow{5}{*}{151000} \\
\hline $100000-200000$ & 119 & 49.2 & \\
\hline $200000-300000$ & 28 & 11.6 & \\
\hline $300000-400000$ & 8 & 3.3 & \\
\hline$>400000$ & 3 & 1.2 & \\
\hline \multicolumn{4}{|l|}{ Years living in the area } \\
\hline $30-34$ & 69 & 28.5 & \multirow{4}{*}{43} \\
\hline $35-40$ & 91 & 37.6 & \\
\hline $41-50$ & 44 & 18.2 & \\
\hline$\geq 51$ & 38 & 15.7 & \\
\hline
\end{tabular}

Source: Field survey, 2013. 


\subsection{Perception towards Climate Variability and Change}

Figure 1 shows respondents' perception towards climate variability and change. Majority of the local people interviewed have a very good knowledge of climate variability and change. The knowledge is important as it will determine the adaptation strategies to be adopted in combating the impacts of climate variability and change on their environment. Majority (78\%) of the respondents agreed that temperature has increased over the last 30 years, and is likely to increase in our lifetime as perceived by $84 \%$. This agreed with the work of Ishaya and Abaje (2008) in which $73 \%$ of the respondents were on the opinion that temperature has been increasing over the past few decades. This is also in agreement with the study of Oladipo (2011) that the country has been experiencing temperature increase of about $0.2{ }^{\circ} \mathrm{C}-0.3{ }^{\circ} \mathrm{C}$ per decade in all its ecological zones. About $52 \%$ of the respondents opined that rainfall has decreased over the last 30 years with increased variability as perceived by $56 \%$ of the respondents. The decreased in rainfall is in variance with related studies in the area. For examples Ati, Iguisi, and Afolayan (2007), Ati, Stigter, Iguisi, and Afolayan (2009), Odekunle, Andrew, and Aremu (2008), Abaje et al. (2012), and Abaje et al. (2013) using recorded rainfall data observed that this zone is now experiencing wetter conditions in recent years. Majority $(65 \%)$ of the local people are expecting rainfall to increase in our lifetime.

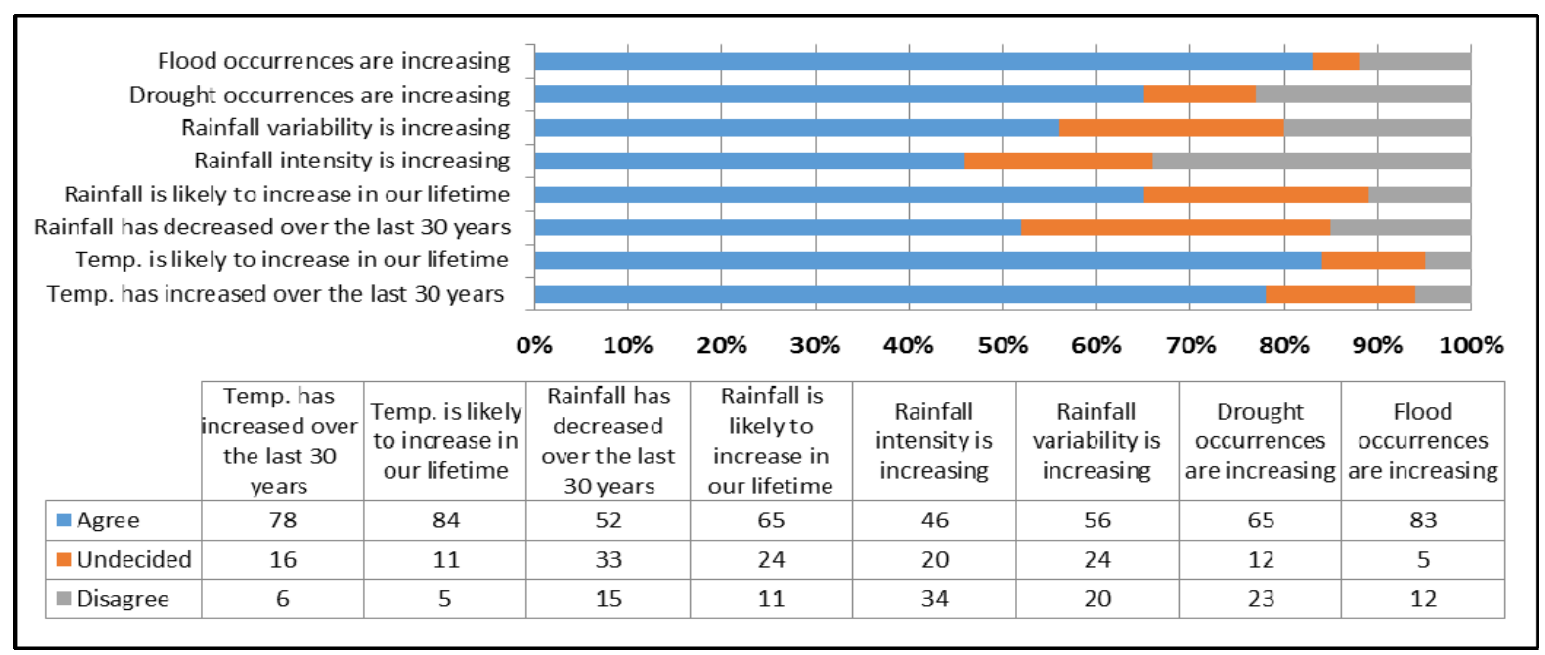

Figure 1. Perception towards climate variability and change

In terms of drought occurrences, $65 \%$ of the respondents agreed that drought occurrences are on the increase while $23 \%$ disagreed. This is also in variance with most of the recent researches related to drought occurrences in the northern parts of the country using recorded climatic data. For examples, Ati et al. (2007 \& 2009), Odekunle et al. (2008), and Abaje et al. (2012 \& 2013) observed that drought occurrences in this zone is decreasing in recent years. $83 \%$ of the people perceived that flood occurrences are increasing. Records have shown that this extreme weather event (flood) is becoming an annual occurrence in the northern parts of the country leading to loss of lives and property, especially, in the Sudano-Sahelian Ecological Zone of Nigeria.

\subsection{Perceived Causes of Climate Variability and Change}

Respondents perceived causes of climate variability and change is shown in Figure 2. A significant number $(83 \%)$ of the respondents opined that community disobeying God is one of the major causes of climate variability and change. This result is in good agreement with the findings of Farauta, Egbule, Idrisa and Agu (2011), and that of Manyatsi, Mhazo and Masarirambi (2010) in which community disobeying God was ranked $3^{\text {rd }}$ as the major causes of climate variability and change by the rural communities in Swaziland. The perceived causes of climate variability and change that were scientifically proven includes: industrial pollution, destruction of nature, combustion of fossil fuel among others (Manyatsi et al., 2010; Ajaero, Akukwe, \& Asuoha, 2010; Igwebuike, Odoh, Ezeugwu, Oparaku, \& Oparaku, 2010; Odjugo, 2010). 


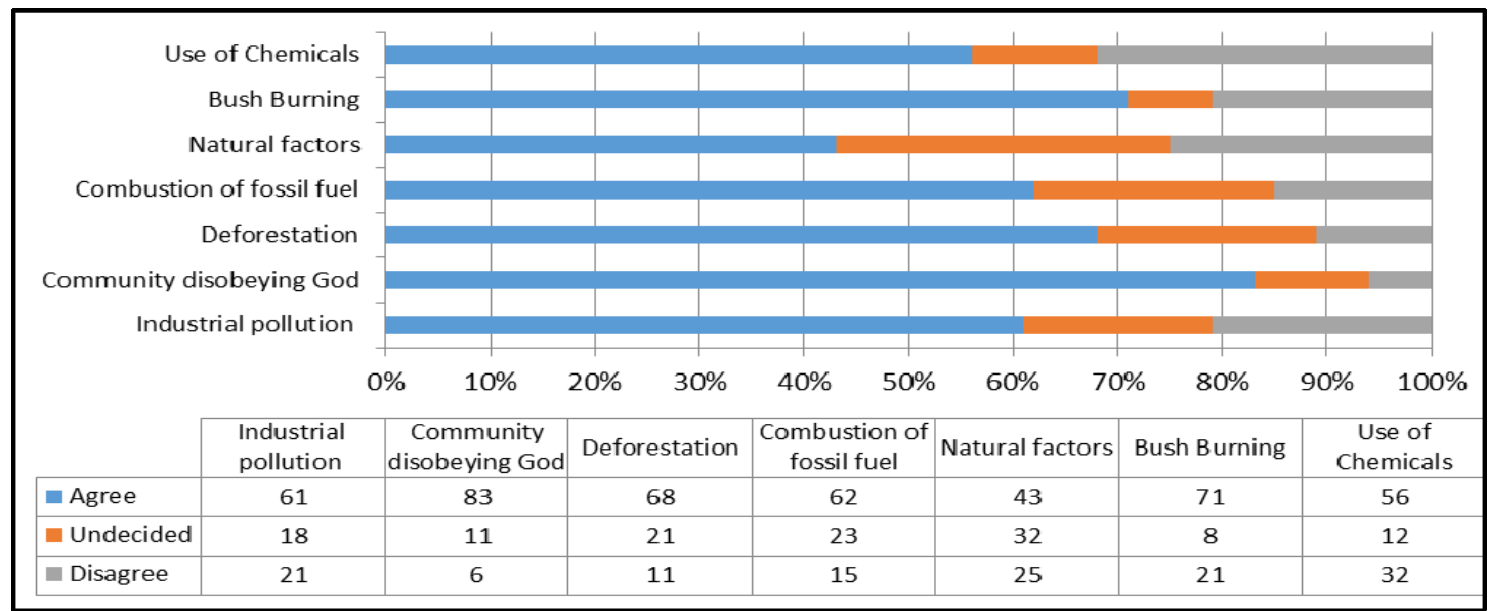

Figure 2. Causes of climate variability and change

Out of the 242 respondents, $61 \%$ agreed that industrial pollution is one of the major causes of climate variability and change. Considering combustion of fossil fuel, $62 \%$ believed it is another major cause of climate change. This result revealed that some of the respondents are aware of the scientific proven causes of climate change. In terms of natural factors, $43 \%$ of the people studied are in agreement of the fact that natural factors such as changes in volcanic activity and solar output are some of the causes of climate change, $25 \%$ disagreed while $35 \%$ were neutral. This implies that most of the local people are not aware of natural factors (natural internal processes or external forcing) in causing climate variability and change as stated in the IPCC (2007a) report. $68 \%$ and $71 \%$ are aware of deforestation and bush burning respectively in causing climate variability and change. This may be as a result of the fact that the local people depend solely on the vegetation as a source of fuel wood and fodder for livestock; and the soil for farming. As a result, they are very conscious that deforestation and bush burning will continue to accelerate the degradation of the soil condition of their environment to desert-like conditions. Responding to the issue of using chemicals, $56 \%$ are of the believed that the use of chemicals on land and in water is contributing to climate change. Some of these chemicals lead to deterioration of soil, and they also have some effects on the atmosphere and hydrosphere.

\subsection{Impacts of Climate Variability and Change as Perceived by the Local People}

The perceived impacts of climate variability and change by the respondents are presented in Table 2 . The most significant impacts as perceived by the local people in the study area are decline in crop yields with a mean score $(\bar{x})$ of 4.61 , water shortages $(\bar{x}=4.58)$, decrease in soil fertility $(\bar{x}=4.39)$, and rural-urban migration $(\bar{x}=$ 4.18). On the other hand, the yearly rains are not supporting crop production as before, increase incidences of droughts during the raining season, and increasing death of livestock were not taken as significant impacts of climate variability and change in the study area by the respondents.

The high impacts of climate variability and change on decline in crop yields cannot be unconnected with the increase in temperature, high rainfall variability, and high incidence of flood occurrences in the area that resulted to low crop yield. The implication is the increased cost of food crops in the area. A male respondent in the FGD reported that 'the harvested food crops hardly sustain them for six months, as a result of that, he always engage in petty trading in order to augment the food shortage in his family'. Since the soil is now becoming infertile due to deforestation and bush burning and hence, not supporting crops as before, is one of the major causes of rural-urban migration in the area according to a respondent in the FGD. The increase in temperature, high inter-annual rainfall variability, floods and drought incidences have been leading to crop infestation and diseases. The communities are therefore exposed to these extreme climate events and indirectly though changes in water, air, food quality and quantity, agriculture and livelihoods. These direct and indirect exposures can cause death, disability and hardship in the study area. The results of the respondents is in line with the report of the IPCC (2007b) that increases in climate extremes (e.g., storms, floods, temperature, droughts) associated with climate variability and change would cause deaths and injuries, population displacement, and adverse effects on food production, freshwater availability and quality, and would increase the risks of infectious disease, particularly in low-income regions. 
Table 2. Respondents' perceived impacts of climate variability and change

\begin{tabular}{lcc}
\hline Impacts of Climate Variability and Change & Mean Score & Rank \\
\hline Climate variability and change will result to decline in crop yields. & $4.61^{*}$ & 1 \\
The yearly rains are not supporting crop production as before. & 2.42 & 10 \\
Climate variability and change has lead to crop infestation and diseases. & $3.09^{*}$ & 8 \\
The cost of food crops are increasing because of climate change. & $3.25^{*}$ & 7 \\
Climate variability and change lead to rural-urban migration. & $4.18^{*}$ & 4 \\
Decline in forest resources due to climate change. & $3.80^{*}$ & 5 \\
There have been increase incidences of floods during the raining season. & $3.37^{*}$ & 6 \\
There have been increase incidences of droughts during the raining season. & 2.39 & 11 \\
There is decrease in soil fertility & $4.39^{*}$ & 3 \\
Death of livestock is increasing & 2.55 & 9 \\
Water shortages & $4.58^{*}$ & 2 \\
\hline
\end{tabular}

Note: *Significant impacts.

Source: Field survey, 2013.

Another significant impacts of climate variability and change as perceived by the respondents is water shortages. This is true as the researcher during his field observation saw long queues of people searching for water in public taps and boreholes; while some resort to buying from water vendors in which the source of the water is always doubtful. Water shortages in the area might have been aggravated by the increase in population during the last 30 years and the influx of people as a result of the establishment of the Federal University Dutsin-Ma in 2010.

\subsection{Adaptation Strategies in Combating Impacts of Climate Variability and Change}

Climate variability and change are already having severe impacts on local people's livelihoods, particularly those that are highly dependent on natural resources for farming and livestock production. Table 3 shows the adaptation strategies adopted by the local people in combating impacts of climate variability and change. The most significant strategies adopted by the respondents are water harvesting $(\bar{x}=4.51)$, used of fertilizer/animals dung to improve crop yield $(\bar{x}=4.49)$, and prayers for God to intervene $(\bar{x}=4.41)$. Prayers for God or Allah to intervene is in agreement with the findings of Farauta et al. (2011) in which $88.2 \%$ of the respondents were on the opinion that prayers is one of the major strategies of combating the impacts of climate variability and change. Others that are not significant as perceived by the local people are attending enlightenment programs on climate change and access to credit community based loaning institution.

Table 3. Adaptation strategies to mitigate impacts of climate variability and change

\begin{tabular}{lcc}
\hline Adaptation Strategies & Mean Score & Rank \\
\hline Selling of livestock to augment cost of crop production & $4.37^{*}$ & 4 \\
Planting of drought resistant crops & $3.49^{*}$ & 8 \\
Planting of crop varieties with a wide range of maturity and climatic variability & & \\
tolerance & $3.57^{*}$ & 7 \\
Engaging in irrigation agriculture during dry season & $3.72^{*}$ & 5 \\
Planting of crops on flood plain during dry season & $3.65^{*}$ & 6 \\
You used fertilizer/animals dung to improve crop yield & $4.49^{*}$ & 2 \\
You have access credit based loaning institution in your community & 2.48 & 9 \\
Pray for God to intervene & 4.41 & 3 \\
You have attended enlightenment programs on climate change before & 2.33 & 10 \\
Water harvesting & $4.51^{*}$ & 1 \\
\hline
\end{tabular}

Note: *Significant adaptation strategies.

Source: Field survey, 2013. 
Selling of livestock to augment cost of crop production is not a sustainable strategy for combating the impacts of climate variability and change. This is because most of the local people rely on the cattle as a source of draught for ploughing, collection of firewood, conveyance of manure to the farms and harvested crops from the farms. The milk obtained from cows is also a source of proteins. But in a situation where these animals are sold, most of the local people have to resort to manual farming especially if they do not have enough money to hire tractors or oxen for draught power. The implication is the inability of food to sustain such families to the next season. Other implications include the shortages of animals' dung that will be used to improve crop yield and the lack of proteins in their diet. Water harvesting, used of fertilizer/animals dung to improve crop yield, engaging in irrigation agriculture during dry season, planting of drought resistant crops, planting of crops on flood plain during dry season, and planting of crop varieties with a wide range of maturity and climatic variability tolerance are sustainable adaptation strategies.

In terms of praying for God's intervention as adaptation strategy, a farmer said that whenever there is delay in the onsets of the rain, or rainfall variability resulting in dry spells or floods, or there is crop infestation, the whole community would gather in one place for a special prayer and Allah (God) always answer their prayers.

Adequate information on climate variability and change is still lacking in the study area as enlightenment programs on climate change are poorly attended because these programs are perceived as not significant adaptation strategies by the communities.

\section{Conclusions}

The results of this study revealed that the local people have a good knowledge of climate variability and change even though a significant percentage $(83 \%)$ of the respondents attributed climate variability and change to non-scientifically proven causes (community disobeying God). Findings also revealed that climate variability and change are already having severe impacts on the local people's livelihoods in the study area; this is because they depend highly on natural resources for farming and livestock production.

The most significant adaptation strategies adopted by the respondents that are sustainable are water harvesting and the use of fertilizers/animals' dung to improve crop yield. Selling of livestock to augment cost of crop production as adaptation strategy is not sustainable.

It is recommended that strategies for combating the impacts of climate variability and change should take into account the traditional and religious beliefs of the people. There is also need to educate local communities to appreciate the scientific basis of climate variability and change so that when coupled with beneficial tradition and religious beliefs, these communities may be able to combat the impacts of climate variability and change using locally available resources. Enlightenment programs on climate variability and change can be done through radio and television programs, issuance of newsletter, booklets, reports, and videos containing information and advice on mitigating strategies that are sustainable to the local people. Lastly, this research is a general attempt to fill some gaps in the present knowledge on climate variability and change in Dutsin-Ma LGA of Katsina State. Thus, there is a definite need to further study the vulnerability of climate variability and change in the area.

\section{References}

Abaje, I. B. (2007). Introduction to soils and vegetation. Kafanchan: Personal Touch Productions.

Abaje, I. B., Ati, O. F., \& Iguisi, E. O. (2012). Changing climatic scenarios and strategies for drought adaptation and mitigation in the Sudano-Sahelian Ecological Zone of Nigeria. In M. A. Iliya \& I. M. Dankani (Eds.), Climate Change and Sustainable Development in Nigeria (pp. 99-121). Ibadan: Crown F. Publishers.

Abaje, I. B., Ati, O. F., Iguisi, E. O., \& Jidauna, G. G. (2013). Droughts in the Sudano-Sahelian Ecological Zone of Nigeria: Implications for Agriculture and Water Resources Development. Global Journal of Human Social Science (B): Geography, Geo-Sciences \& Environmental, 13(2), 1-10.

Abaje, I. B., \& Giwa, P. N. (2010). Flood risk assessment and vulnerability in Kafanchan town, Jema'a local government area of Kaduna State, Nigeria. International Journal of Sustainable Development, 3(1), 94-100.

Abraham, F., Bamidele, F. S., Adebola, A. J., \& Kobe, I. H. (2011). Climate change mitigating activities and determinants in the rural guinea savannah of Nigeria. Sustainable Agriculture Research, 1(2), 170-177.

Ajaero, C. K., Akukwe, T. I., \& Asuoha, G. C. (2010). Climate change concepts and issues. In R. N. C. Anyadike, I. A. Madu \& C. K. Ajaero (Eds.), Climate Change and the Nigerian Environment (pp. 1-17). Enugu: Jamoe Publishers (Nigeria).

Ati, O. F., Iguisi, E. O., \& Afolayan, J. O. (2007). Are we experiencing drier conditions in the sudano-sahelian 
zone of Nigeria? J. of Appl. Sci. Res., 3(12), 1746-1751.

Ati, O. F., Stigter, C. J., Iguisi, E. O., \& Afolayan, J. O. (2009). Profile of rainfall change and variability in the northern Nigeria, 1953-2002. Research Journal of Environmental and Earth Sciences, 1(2), 58-63.

Farauta, B. K., Egbule, C. L., Idrisa Y. L., \& Agu, V. C. (2011). Farmer's perceptions of climate change and adaptation strategies in northern Nigeria: An empirical assessment. African Technology Policy Studies Network. Research Paper No. 15. Retrieved from http://www.atpsnet.org/Files/rps15.pdf

Federal Republic of Nigeria. (2012, April). Federal Republic of Nigeria 2006 population and housing census. Priority Table Vol. III. Abuja: National Population Commission.

Federal Republic of Nigeria. (2003). Nigeria's first national communication under the United Nations Framework Convention on Climate Change. The Ministry of Environment of the Federal Republic of Nigeria.

Igwebuike, M. N., Odoh, F. C., Ezeugwu, C. I., Oparaku, N. F., \& Oparaku, O. U. (2010). Climate change concepts and issues. In R. N. C. Anyadike, I. A. Madu \& C. K. Ajaero (Eds.), Climate Change and the Nigerian Environment (pp. 57-64). Enugu: Jamoe Publishers (Nigeria).

IPCC. (2007a). Climate change 2007: synthesis report. In R. K. Pachauri \& A. Reisinger (Eds.), Contribution of Working Groups I, II and III to the Fourth Assessment Report of the Intergovernmental Panel on Climate Change (p. 104). IPCC, Geneva, Switzerland.

IPCC. (2007b). Climate change 2007: Impacts, adaptation and vulnerability. In M. L. Parry, O. F. Canziani, J. P. Palutikof, P. J. van der Linden \& C. E. Hanson (Eds.), Contribution of Working Group II to the Fourth Assessment Report of the Intergovernmental Panel on Climate Change (p. 976). Cambridge, UK: Cambridge University Press.

IPCC. (2007c). Summary for policymakers. In M. L Parry, O. F. Canziani, J. P. Palutikof, P. J. van der Linden \& C. E. Hanson (Eds.), Climate Change 2007: Impacts, Adaptation and Vulnerability (pp. 7-22). Contribution of Working Group II to the Fourth Assessment Report of the Intergovernmental Panel on Climate Change, Cambridge University Press, Cambridge, UK.

Ishaya, S., \& Abaje, I. B. (2008). Indigenous people's perception on climate change and adaptation strategies in Jema'a Local Government Area of Kaduna State, Nigeria. Journal of Geography and Regional Planning, $1(8), 138-143$.

Le Treut, H., Somerville, R., Cubasch, U., Ding, Y., Mauritzen, C., Mokssit, A., ... Prather, M. (2007). Historical Overview of Climate Change. In S. Solomon, D. Qin, M. Manning, Z. Chen, M. Marquis, K. B. Averyt, M. Tignor \& H. L. Miller (Eds.), Climate Change 2007: The Physical Science Basis (pp. 93-127). Contribution of Working Group I to the Fourth Assessment Report of the Intergovernmental Panel on Climate Change. United Kingdom and New York, NY: Cambridge University Press.

Manyatsi, A. M., Mhazo, N., \& Masarirambi, M. T. (2010). Climate variability and change as perceived by rural communities in Swaziland. Research Journal of Environmental and Earth Sciences, 2(3), 164-169.

Nigerian Meteorological Agency. (2012). Introduction. 2012 Nigeria Climate Review (pp. 6-7). Nigerian Meteorological Agency (NIMET), Abuja.

Odekunle, T. O., Andrew, O., \& Aremu, S. O. (2008). Towards a wetter Sudano-Sahelian ecological zone in twenty-first century Nigeria. Weather, 63(3), 66-70. http://dx.doi.org/10.1002/wea.172

Odjugo, P. A. O. (2010). Global and regional analysis of the causes and rate of climate. In R. N. C. Anyadike, I. A. Madu \& C. K. Ajaero (Eds.), Climate Change and the Nigerian Environment (pp. 65-83). Enugu: Jamoe Publishers (Nigeria).

Oladipo, E. (2011). The challenge of climate change for Nigeria: An overview. In E. O. Iguisi, O. F. Ati, R. O. Yusuf \& A. E. Ubogu (Eds.), Climate Change Impacts: Risks and Opportunities, Lead Presenter 2, (pp 22-44). Proceedings of the International Conference of the Nigerian Meteorological Society held at NAERLS Conference Hall, Ahmadu Bello University, Zaria-Nigeria, $13^{\text {th }}$ to $17^{\text {th }}$ November, 2011.

Salick, J., \& Byg, A. (2007). Indigenous peoples and climate change. Tyndall Center for Climate Change Research, Oxford.

Steffen, W. (2009). Climate change 2009: Faster change and more serious risks. Department of Climate Change, Australian Government. Retrieved from http://www.preventionweb.net/files/11032_climatechangefasterchangeandmoreser.pdf 
Tukur, R., Adamu, G. K., Abdulrahid, I., \& Rabi'u, M. (2013). Indigenous trees inventory and their multipurpose uses in Dutsin-Ma area, Katsina State. European Scientific Journal, 9(11), 288-300.

\section{Copyrights}

Copyright for this article is retained by the author(s), with first publication rights granted to the journal.

This is an open-access article distributed under the terms and conditions of the Creative Commons Attribution license (http://creativecommons.org/licenses/by/3.0/). 